UDC 612.017.3: 615.9-099]: 576.8

DOI: $10.21668 /$ health.risk/2017.3.15.eng

\title{
EXPERIMENTAL MODELING OF AEROSOLS PRODUCED BY MICROORGANISMS IN WORKING AREA AIR AS RISK FACTOR EXERTING HAZARDOUS IMPACTS ON HEALTH OF WORKERS EMPLOYED AT BIOTECHNOLOGICAL PRODUCTION
}

\author{
N.V. Dudchik, V.A. Filonyuk, V.V. Shevlyakov, S.I. Sychik, O.E. Nezhvinskaya \\ Scientific-practical Hygiene Center, 8 Akademicheskaya Str., Minsk, 220012, Republic of Belarus
}

Scientific foundation and practices in the sphere of hygienic and ecological standardization concerning biological factors of the environment have a number of peculiarities and are methodically less developed than chemical factors standardization. Efficient industrial control over maximum permissible concentrations of standardized microorganisms-producers in working area air is based on validated instrumental techniques of quantitative assessment. Our goal was to create experimental models for microorganisms-producers' aerosols of a multi-component microbe specimen in working area air as a risk factor causing impacts on health of workers employed at biotechnological production; another task was to work out a procedure for measuring Pseudomonas aurantiaca B-162/255.17concentration and cells and spores of Bacillus sp. BB58-3 strain in working area air. We gave grounds for a technology aimed at quantitative determination of microorganismsproducers in working area air in a modeling experiment; it was based on conventional stages and techniques accepted in microbiological practices, namely air samples taking via aspiration technique allowing for a volume taken; cultivation under conditions which are optimal for examined microorganisms-producers in a nutrient medium with reduced composition; calculation of evolved colonies with specific morphological features; morphologic identification of microorganisms and colonies; calculation of microorganisms' quantity on dishes with recalculation per $1 \mathrm{~m}^{3}$ of air. Basing on the detected regular concentration dependences of microbe contamination dynamics in air we worked out a procedure for quantitative determination of microorganisms-producers; we also performed metrological estimate of operational properties for assessing microorganisms-producers of a multi-component microbe specimen as a risk factor causing hazardous impacts on health of workers employed at biotechnological production. We validated our measuring procedure in conformity with the requirements set forth by ISO.

Key words: biological factor, modeling experiment, microorganisms-producers, multi-components microbe specimens, working area air, hygienic standards, biotechnological production.

Development of biotechnological industry which belongs to high-tech $\mathrm{V}$ and VI social and economic structure is in line with national interests and long-term goals of sustainable social and economic improvements in Belarus [4]. Basic trends in industrial and medical biotechnology are based on application of various stems, species, strains, and serotypes of natural or mutagenic microorganisms including those obtained via genetic engineering as probiotic food preparations, protein producers, biologically active substances and enzymes (amylolytic, proteolytic, pectolytic, cellulo-

CC Dudchik N.V., Filonyuk V.A., Shevlyakov V.V., Sychik S.I., Nezhvinskaya O.E., 2017

Natalia V. Dudchik - Doctor of Biological Sciences, Associate Professor, Head of Microbiology Labora-

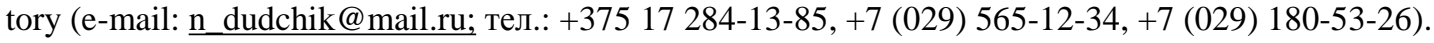

Vasiliy A. Filonyuk - Candidate of Medical Sciences, Associate Professor, leading researcher at Industrial Toxicology Laboratory, (e-mail: rspch@rspch.by; тел.: +375 17 284-08-67).

Vitaliy V. Shevlyakov - Doctor of Medical Sciences, Professor Chief researcher at Industrial Toxicology Laboratory (e-mail: rspch@rspch.by; тел.: +375 17 284-08-67).

Sergei I. Sychik - Candidate of Medical Sciences, Associate Professor, Director (e-mail: rspch@ @rspch.by; тел.: +375 17 284-08-67).

Ol'ga E. Nezhvinskaya - Junior researcher at Microbiology Laboratory (e-mail: rspch@ rspch.by; тел.: +375 17 284-08-67). 
lytic, various antibiotics, amino acids, vitamins, and others), and microbiological specimens for biological protection and increase in cropping power of crops etc [15-19]. However, industrial environment and atmosphere contamination with microorganisms-producers and microbe specimens made on their base is quite possible in the process of their application; they can also penetrate working area air and atmosphere and exert adverse influence on workers' and population's health $[2,3,6,9,12$, 13, 14]. Microorganisms-producers occurrence in working area air and direct contact with microbe aerosols in the process of their application in industrial conditions can be health risk factors for workers employed at biotechnological productions as industrial strains of microorganismsproducers are low-pathogenic but they still have great or apparent sensitizing abilities (1-2-degree of allergenic danger) [13, 14].

Therefore, examination of microorganisms properties seems to be vital and practically significant; it is also essential to assess dangers and possibilities of consequences which biotechnological production can have and which can be dangerous for human health. Biotechnological products can contain viable cells and their structural elements; so it is necessary to work out efficient medical prevention activities aimed at elimination of their adverse impacts via hygienic standardization and control over their contents in objects of living environment. Scientific foundation and practices of hygienic and ecological standardization of biological factors in living environment have a number of peculiarities and they are methodically less developed than those related to chemical factors. Development of methodology and techniques for hygienic regulation and standardization of microorganisms-producers and microbe specimens as biological factors of living environment is one of the leading scientific trends pursued now by Scientific and Practical Center for Hygiene of Belarus Public Health Ministry; here a scientific school has been created within the frameworks of this promising trend in preventive medicine. As a result of performed complex toxicological-hygienic research hygienic standardization of more than 100 microbe specimens has been accomplished; maximum permissible concentrations (MPC) in working area air were fixed for 12 new one- and multi-component microbe specimens $[1,3,5-$ $8,10,11]$.

Efficient industrial control over MPC of standardized microorganisms-producers and microbe specimens in working area air is based on application of validated instrumental techniques of quantitative assessment.

Creation of standardized and validated measuring techniques for microorganismsproducers and microbe specimens concentrations in working area air is a quite complicated analytical task as experimental modeling of microbe aerosols includes optimization of all instrumental technique parameters (air sampling conditions under various microbe loads, microorganismsproducers cultivating and identification etc), determination of analytical properties related to specificity and selectivity, concentration dependences and sensitivity limits of a created technique. Methodical techniques and calculation algorithms for operational characteristics are worked out for such matrixes as water media or food products, but there aren't any such techniques for assessing metrological parameters of measuring biological factors in air medium[6,7].

Our goal was to create experimental models of microorganisms-producers aerosols of a multi-component microbe specimen as a health risk factor for workers em- 
ployed at biotechnological production; another goal was to work out a technique for measuring concentrations of Pseudomonas aurantiaca B-162/255.17, and cells and spores of Bacillus sp. BB58-3 strain in working area air.

Data and methods Our research object was «Profibactтм-Phyto», a new microbe specimen based on Pseudomonas aurantiaca B-162/255.17 cells, and cells and spores of Bacillus sp. BB58-3 strain, created by the Institute for Genetics and Cytology of Belarus National Academy of Science.

We applied a system for liquid aerosols creation in inoculation chambers with volume equal to 250 liter (Spectrolab, RF); SAS SUPER100 aspirator (PBI International, Italy), as well as standard microbiological laboratory equipment. Measuring devices and basic equipment were properly verified and gauged.

Nutrition media. We applied selective medium with the following composition: 10.0 grams of tryptone; 1.0 gram of yeastrel; 0.02 grams of water-free calcium chloride; 15 grams of microbiological agar. To create working microbe specimen dilutions, we applied phosphate buffer solution with $0.1 \%$ peptone, $\mathrm{pH} 7,0$. We confirmed microbe cells contents in a working culture via seeding a reduced composition on a selective agar medium. To optimize sampling parameters and to determine operating characteristics of a detector (contact Petri dishes with a relevant nutrition medium) we applied working dilution of a specimen, namely $106 \mathrm{CFU} / \mathrm{ml}$.

At the following stages in our experimental modeling of microbe aerosol in an inoculation chamber we took air samples within 10-50 liters volume range. Air samples were taken via aspiration technique on the surface of an agar selective medium with the said structure in two replications; they were then incubated for $(48 \pm 2)$ hours at $(30 \pm 0,5){ }^{\circ} \mathrm{C}$; after that grown typical microorganisms-producers colonies were calculated. We assessed cultural and morphological peculiarities of evolved colonies and calculated quantity of typical ones.

Microorganisms-producers concentration $\mathrm{X}, \mathrm{CFU} / \mathrm{m} 3$, was calculated as per formula:

where:

$$
X=(N \cdot 1000) / V,
$$

$\mathrm{X}$ is concentration of microbe cells and spores in working area air;

$\mathrm{N}$ is quantity of microorganismsproducers colonies on a dish;

1000 is a coefficient of recalculation per $1 \mathrm{~m} 3$ of air;

$\mathrm{V}$ is a volume of a taken air sample, dm3.

Results and discussion MP of Bacillus and Pseudomonas stems are used to biologically stimulate agriculture crops growth and development; they can also be used as a biological protector (Table 1).

Hygienic standards of microbe specimen MPC in working area air are fixed at the level of 5,000 CFU (microbe cells) per $1 \mathrm{~m} 3$ for Pseudomonas aurantiaca B162/255.17 and Bacillus sp. BB58-3, IV danger category [8].

The created technology of MP quantitative assessment in working area air in our model experiment is based on conventional stages and techniques of microbiological practices: air sampling via aspiration technique allowing for the volumes taken; cultivating on a nutrition medium with reduced composition under conditions which are optimal for the examined microorganisms-producers; calculation of evolved colonies with specific morphological features; morphological identification of microorganisms and colonies; calculation of microorganisms quantities on dishes with recalculation as per $1 \mathrm{~m} 3$ of air. 
Profibact TM-Phyto MP Properties

\begin{tabular}{|l|l|}
\hline Sources of strains-producers & \multicolumn{1}{|c|}{ Morphological, cultural and biochemical features of strains } \\
\hline $\begin{array}{l}\text { Bacillus sp. BB58-3 is ob- } \\
\text { tained via induced muta- } \\
\text { genesis of a natural strain, } \\
\text { antagonist to plant- } \\
\text { pathogenic fungi, is not } \\
\text { plant-toxic, stimulates plants } \\
\text { growth }\end{array}$ & $\begin{array}{l}\text { Bacillus sp. BB58-3. Immovable gram-positive spores-producing } \\
\text { straight bacilli with rounded ends, 0.6 x 3-4 } \mu \text { m size. Colonies are } \\
\text { small (1.0-3.0 mm) and rounded, flat-convex, with even blade ends, } \\
\text { cream colored, non-transparent, with heterogeneous internal struc- } \\
\text { ture. Catalase-positive, thermal-stable, obligate aerobe with proteo- } \\
\text { lytic and amylolytic activity. }\end{array}$ \\
$\begin{array}{l}\text { Pseudomonas aurantiaca } \\
\text { - 162/255.17 is obtained } \\
\text { via multi-stage mutagenesis } \\
\text { of a natural strain }\end{array}$ & $\begin{array}{l}\text { P. aurantiaca B-162/255.17. Mobile, gram-negative, stright bacilli } \\
\text { with rounded ends, 0.6 x 2-3 } \mu \text { m sized, with 2-4 monopolar flagella. } \\
\text { Colonies are smooth, flat, with even ends, 2-3 mm in size, yellow- } \\
\text { orange, with homogenous internal structure. Obligate aerobe; synthe- } \\
\text { sizes phenazine antibiotics. As nitrogen, it utilizes ammonium salts, } \\
\text { urea, and nitrates. }\end{array}$ \\
\hline
\end{tabular}

We created a model of spraying in inoculation chambers with 250 liters volume to obtain inhalation modeling of liquid sprays; it allowed us to test regimes of MP concentrations range creation in a closed space with the use of various types of sprayers; with various rates of feeding onto ejectors and air flow sprayers; under various exposures to MS spraying. We optimized parameters of air sampling via aspiration (time and volume) under different microbe loads; we also did it for media compositions and cultivating regimes for microorganisms-producers with their consequent identification. The obtained experimental database allowed us to reveal nature and peculiarities of microorganismsproducers growth depending on microbe specimen concentration in a fixed volume of an inoculation chamber (Figure).

The nature of dependence between a number of colonies on a dish and taken air volume was linear and could be given with an equation given on Figure. Coefficients of $\mathrm{R}^{2}$ determination were within 0.93-0.96 range and it proved that the obtained results of quantitative assessment of MP concentrations in working area air were really authentic.
Operational characteristics for metrological attestation of the quantitative assessment technique were estimated in con formity with the requirements set forth by the International Standardization Organization (ISO): precision parameters (repeatability and intermediate precision with "operator" changing factor) were determined; extended uncertainty was applied as well as other operational characteristics; such parameters as specificity, sensitivity, frequency of false-positive and false-negative results which are inherent in biological factors assessment were taken into account [8, 11].

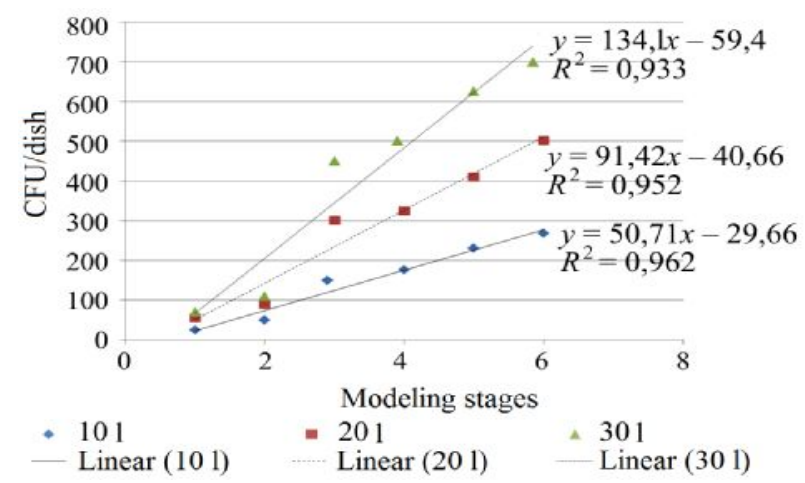

Figure. Dynamics of Pseudomonas aurantiaca $B-162 / 255.17$ and Bacillus sp. BB583 strain producers growth in a modeling experiment 
Basing on the database obtained in the course of the modeling experiment we assessed operational characteristics of the techniques, carried out the metrological attestation and fixed quantitative assess- ment techniques for calculating MP concentrations in working area air [5]. Table 2 contains metrological characteristics and specificity and selectivity parameters of the created techniques.

Metrological characteristics and specificity and selectivity parameters of the created techniques

\begin{tabular}{|c|c|c|c|}
\hline \multirow[b]{2}{*}{$\begin{array}{l}\text { Metrological characteristics } \\
\text { Specificity and selectivity parameters }\end{array}$} & \multirow[b]{2}{*}{$\begin{array}{c}\text { Assessment } \\
\text { type }\end{array}$} & \multicolumn{2}{|c|}{ Value } \\
\hline & & $\begin{array}{l}\text { Pseudomonas au- } \\
\text { rantiaca } \\
\text { B-162/255.1 }\end{array}$ & Bacillus sp. BB58-3 \\
\hline $\begin{array}{l}\text { Weighted aggregate relative standard deviation } \\
\text { in calculation }\end{array}$ & A & \multicolumn{2}{|c|}{0.052} \\
\hline Standard repeatability deviation $\mathrm{Sr}$ & A & \multicolumn{2}{|c|}{$0.012 \log 10 \mathrm{CFU} / \mathrm{m} 3$} \\
\hline Repeatability limit $\mathrm{r}$ & A & \multicolumn{2}{|c|}{$0.034 \log 10 \mathrm{CFU} / \mathrm{m} 3$} \\
\hline $\begin{array}{l}\text { Standard intermediate precision (intra- } \\
\text { laboratory reproducibility) deviation отклоне- } \\
\text { ние промежуточной } \mathrm{Sl}(\mathrm{O}) \text { ) }\end{array}$ & A & \multicolumn{2}{|c|}{$0.147 \log 10 \mathrm{CFU} / \mathrm{m} 3$} \\
\hline Intermediate precision limit $\mathrm{rl}(\mathrm{O})$ & A & \multicolumn{2}{|c|}{$0.41 \log 10 \mathrm{CFU} / \mathrm{m} 3$} \\
\hline Extended uncertainty $(\mathrm{k}=2) \mathrm{U}$ & A & \multicolumn{2}{|c|}{$0.30 \log 10 \mathrm{CFU} / \mathrm{m} 3$} \\
\hline Sensitivity & A & 1.0 & 0.96 \\
\hline Specificity & A & 0.8 & 0.6 \\
\hline False-positive results frequency & A & 0.038 & 0.074 \\
\hline False-negative results frequency & A & 0 & 0.25 \\
\hline Selectivity & A & 1.415 & 1.431 \\
\hline efficiency & A & 0.97 & 0.93 \\
\hline Upper limit of linearity & A & $\begin{array}{l}\text { Not more than } 150 \\
\text { typical colonies per } \\
\text { dish with total num- } \\
\text { ber of colonies being } \\
\text { not more than } 300\end{array}$ & $\begin{array}{l}\text { Not more than } 150 \\
\text { typical colonies per } \\
\text { dish with total num- } \\
\text { ber of colonies being } \\
\text { not more than } 300\end{array}$ \\
\hline
\end{tabular}

Conclusion. As a result of our experiment on modeling multi-component microbe specimen aerosols in working area air we obtained dependences of microorganismsproducers contents in sequential experiment stages and created a quantitative assessment technique to calculate them.

We assessed operational characteristics of the technique aimed at determining Pseudomonas aurantiaca B-162/255.17 and Bacillus sp. BB58-3 strains in air; we also created quantitative assessment techniques for calculating microbe specimen concentrations in working are air and this technique was certified by Belarus State Metrology Institute.

Application of this quantitative assessment technique in the sphere of microbiological laboratories certification provides objective sanitary and industrial control over these microbe specimen contents in working environment as per their conformity to MPC. Scientifically grounded unified approaches to creation of quantitative assessment techniques aimed for calculating multicomponent microbe specimen concentrations in working area air are formalized in a form of application instructions and allow to create similar quantitative assessment tech- 
niques for new biological specimens when these specimens are to be assessed as health risk factors which can possibly exert nega- tive impacts on health of workers employed at biotechnological productions.

\section{References}

1. Dudchik N.V., Shevlyakov V.V. Modelirovanie biologicheskogo deistviya faktorov sredy obitaniya s tsel'yu ikh gigienicheskoi otsenki na osnove prokarioticheskikh test-modelei [Modeling of biological impacts by environmental factors in order to perform their hygienic assessment on the basis of procaryotic test-models]. Biologicheskii faktor i mikrobiologicheskaya diagnostika pri formirovanii zdorovogo obraza zhizni: materialy 12-i Evraziiskoi nauch. konferentsii «Donozologiya-2016» 15-16 dekabrya $2016 \mathrm{~g}$. [Biological factor and microbiological diagnostics when creating healthy lifestyle: amterials of the 12th Eurasian scientific conference «Pre-nosology 2016» December 15-16 2016.]. In: M.P. Zakharchenko, ed. St. Petersburg, 2016, pp. 130-133 (in Russian).

2. Budanova E.V., Sheina N.I., Skryabina E.G., Ivanov N.G., Vorob'ev A.A., Zverev V.V. Izuchenie bezopasnosti biotekhnologicheskikh shtammov mikroorganizmov s tsel'yu ikh gigienicheskogo normirovaniya [Comparative studies of microbial strains used in biotechnology for the elaboration of biosafety standards]. Vestnik Rossiiskoi akademii meditsinskikh nauk, 2010, no. 11, pp. 42-46 (in Russian).

3. Shevlaykov V.V., Filanyuk V.A., Studenichnik T.S., Erm G.I., Dudchik N.V. K voprosu o gigienicheskom normative soderzhaniya $\mathrm{v}$ vozdukhe rabochei zony mikrobnogo preparata Stimul [Hygienic regulations of the microbial medication "Stimul" content in the working area air]. Meditsinskii zhurnal, 2013, no. 4, pp. 135-139 (in Russian).

4. Kolomiets E.I., Raketskaya O.A. Sostoyanie i perspektivy razvitiya biotekhnologii v Respublike Belarus' [Development of biotechnologies in Belarus: contemporary state and prospects]. Mikrobnye biotekhnologii: fundamental'nye i prikladnye aspekty: sbornik nauchnykh trudov [Microbe biotechnologies: fundamental and applied aspects: collection of scientific papers]. Minsk, 2013, vol. 5, pp. 3-9 (in Russian).

5. Metodika vypolneniya izmerenii (MVI) kontsentratsii kletok shtamma Pseudomonas aurantiaca V-162/255.17, kletok i spor shtamma Bacillus sp. BB58-3 - produtsentov mikrobnogo preparata «Profibakttm-Fito»: MVI.MN 5321-2015 : svidetel'stvo ob attestatsii № 896/2015 ot 31.08.2015 g. [Measuring procedure for Pseudomonas aurantiaca B-162/255.17 strain cells concentration, Bacillus sp. BB58-3 strain cells and spores as producers of microbe specimen «Profibakttm-Fito»: МВИ.MH 5321-2015 : certificate No. 896/2015 issued on August 31, 2015]. created by: N.V. Dudchik, V.V. Shevlyakov, V.A. Filonyuk, O.E. Nezhvinskaya. Minsk, Belorusskii gosudarstvennyi institute metrologii, Publ., 2015, 23 p. (in Russian).

6. Shevlyakov V.V., Filonyuk V.A., Erm G.I., Chernyshova E.V., Ushkov S.A., Buinitskaya A.V., Studenichnik T.S. O metodologii gigienicheskogo reglamentirovaniya mikroorganizmov-produtsentov i mikrobnykh preparatov v vozdukhe rabochei zony [On the methodology of hygienic regulation of microorganisms-producents and microbial compositions in the workplace air]. Meditsinskii zhurnal, 2014, no. 2, pp. 40-53 (in Russian).

7. Shevlyakov V.V., Filonyuk V.A., Studenichnik T.S., G Erm.I., Dudchik N.V. Obosnovanie predel'no dopustimoi kontsentratsii (PDK) v vozdukhe rabochei zony mikrobnogo preparata Betaprotektin [Substantiation of the maximum allowable concentration (MAC) in the working area"s air of the mi-crobial medication Betaprotectine]. Meditsinskii zhurnal, 2013, no. 2, pp. 123-126. (in Russian). 
8. Shevlyakov V.V., Filonyuk V.A., Dudchik N.V., Erm G.I., Studenichnik T.S., Kozlova T.O., Chernyshova E.V., Sobol' Yu.A., Buinitskaya A.V., Nezhvinskaya O.E., Yanetskaya S.A., Sychik L.M. Obosnovanie predel'no dopustimykh kontsentratsii i metodik vypolneniya izmerenii soderzhaniya $\mathrm{v}$ vozdukhe rabochei zony mikroorganizmov-produtsentov i mikrobnykh preparatov na ikh osnove: instruktsiya po primeneniyu № 009-1015 [Foundation of maximum permissible concentrations in working area air and measuring techniques for microorganismsproducers and microbe specimen based on them: application instruction no. 009-1015]. Minsk, Nauchno-prakticheskii tsentr gigieny, 2015, 30 p. (in Russian).

9. Pivovarov Yu.P., Sheina N.I., Ivanov N.G., Korolik V.V., Skryabina E.G. Problemy i perspektivy gigienicheskogo normirovaniya biotekhnologicheskikh shtammov mikroorganizmov [Problems and perspectives in the hygienic regulation of biotechnological strains of microorganisms]. Gigiena i sanitariya, 2010, no. 5, pp. 9-12 (in Russian).

10. Filonyuk V.A., Shevlyakov V.V., Dudchik N.V., Erm G.I., Ushkov A.A. Razrabotka gigienicheskogo normativa i metoda kontrolya soderzhaniya $\mathrm{v}$ vozdukhe rabochei zony kombinirovannogo mikrobnogo preparata «ProfibaktTM-Fito» [Development of hygienic standard and the method of control of a content in the air of working area of the combined microbial product «Profibakt-Fito»]. Meditsinskii zhurnal, 2015, no. 4, pp. 128-136 (in Russian).

11. Dudchik N.V. [et al.]. Razrabotka i validatsiya metodik vypolneniya izmerenii soderzhaniya odnokomponentnykh mikrobnykh preparatov na osnove shtammov-produtsentov rodov Bacillus i Pseudomonas v vozdukhe rabochei zony [Creation and validation of procedures for measuring one-component microbe specimen content on the basis of strain-producers of Bacillus and Pseudomonas stems in working area air]. Aktual'nye problemy transportnoi meditsiny, 2016, no. 4, pp. 21-29. (in Russian).

12. Sergeyuk N.P., Suprun I.P., Buyanov V.V. Toksikologiya promyshlennykh mikroorganizmov [Industrial microorganisms toxicology]. Moscow, Institut problem khimicheskoi fiziki RAN, Publ., 2003, 127 p. (in Russian).

13. Sosedova L.M., Rukavishnikov V.S., Shayakhmetov S.F. Toksiko-gigienicheskie aspekty otsenki riska izolirovannogo i sochetannogo vozdeistviya biotekhnologicheskikh produktov [Toxicologic and hygienic aspects in evaluating the risk due to isolated and combined action of biotechnologic products]. Meditsina truda i promyshlennaya ekologiya, 2003, no. 3, pp. 15-19 (in Russian).

14. Sheina N.I. Kriterii otsenki biobezopasnosti mikroorganizmov, ispol'zuemykh v biotekhnologicheskoi promyshlennosti [Assessment criteria for biological safety of microorganisms applied in biotechnological industry]. Vestnik Orenburgskogo gosudarstvennogo universiteta, 2012, no. 6, pp. 165-169.

15. Baker M. Ten years of Nature Biotechnology research. Nat. Biotechnology, 2006, vol.24, no.301. DOI: 10.1038/nbt0306-301a

16. Barreto de Castro L.A. Graduate programs in Brazil need reevaluation to contribute for innovation in biotechnology. Biotech. Research and Innovation. Available at: https://doi.org/10.1016/j.biori.2017.01.001 (29.05.2017).

17. Fonseca G.G. [et al.]. The yeast Kluyveromyces marxianus and its biotechnological potential. Appl. Microbiology a. Biotechnology, 2008, vol. 79, no. 3, pp. 339-354.

18. Kumar R., Singh O.V. Biotechnological production of gluconic acid: future and implication. Appl. Microbiol. and Biotechnol, 2007, vol. 75, no. 4, pp. 713-722.

19. Soccol C.R. [et al.]. Recent developments and innovations in solid state fermentation. Biotech. Research and Innovation. Available at: https://doi.org/10.1016/j.biori.2017.01.002 (29.05.2017). 
Dudchik N.V., Filonyuk V.A., Shevlyakov V.V., Sychik S.I., Nezhvinskaya O.E. Experimental modeling of aerosols produced by microorganisms in working area air as risk factor exerting hazardous impacts on health of workers employed at biotechnological production. Health Risk Analysis, 2017, no. 3, pp. 157-134. DOI: 10.21668/health.risk/2017.3.15.eng

Received: 15.06 .2017

Accepted: 19.09 .2017

Published: 30.09.2017 